Andrij MILENIN

Piotr KUSTRA

Miroslaw WRÓBEL

AGH University of Science and Technology

Valeriy PIDVYSOTS'KYY

Łukasiewicz Research Network - Institute for Ferrous Metallurgy

Marek PACKO

AGH University of Science and Technology

\title{
DIELESS DRAWING PROCESS FOR ELONGATION OF THIN COPPER AND COPPER ALLOY WIRE
}

\author{
ZASTOSOWANIE PROCESU CIĄGNIENIA BEZMATRYCOWEGO \\ DO WYDŁUŻENIA CIENKICH DRUTÓW Z MIEDZI I JEJ STOPÓW
}

The article proposes a new process for the production of thin wires made of copper and copper alloys. The proposed process is based on the idea of dieless drawing. The workpiece for dieless drawing is a thin wire obtained through a conventional drawing method. The proposed technology is based on a multi-pass process. The deformation parameters in each pass are determined on the basis of an analysis of the dependence of the flow stress of the material on the strain, strain rate and temperature. For this purpose, plastometric tests of a copper and CuZn37 alloy were performed. In order to determine technological plasticity and roughness propagation during dieless drawing, physical and numerical modelling of this process were performed. The obtained data were used in the practical implementation of the dieless drawing technology.

Keywords: dieless drawing, copper, wire, roughness, plasticity

\section{INTRODUCTION}

The process of dieless drawing is a stretching of a wire, rod or tube with its simultaneous local heating in the deformation zone. The first studies of this process were done by Weiss et al., [1] and were devoted to the production of wire. Dieless drawing allows for elongation of the wire without using a deforming die. This fact is important since in the conventional drawing process the cost of the die is very high. Additionally, dieless drawing has a number of other advantages. For example, Supriadi et al. [2] show that it is possible to vary the stretching and cross-sectional shape of the tubes along their length, which is impossible to obtain with conventional drawing or extrusion. Another ad-

Corresponding Author: milenin@agh.edu.pl
Artykut poświęcono nowemu procesowi produkcji cienkich drutów z miedzi i jej stopów. Zaproponowany proces jest oparty o idee ciagnienia bezmatrycowego. Wsadem do ciagnienia bezmatrycowego jest cienki drut, wyprodukowany za pomoca metody konwencjonalnego ciagnienia. Proponowana technologia jest oparta na wieloprzepustowym procesie. Parametry odkształcenia w każdym przepuście sa wyznaczane na podstawie analizy zależności naprężenia uplastyczniajacego od odksztatcenia, prędkości odksztatcenia i temperatury. W tym celu przeprowadzono badania plastometryczne miedzi i stopu CuZn37. Celem wyznaczenia technologicznej plastyczności oraz propagacji chropowatości powierzchni drutu w trakcie ciagnienia bezmatrycowego wykonano fizyczne i numeryczne modelowanie procesu. Otrzymane dane wykorzystano podczas praktycznej implementacji procesu ciagnienia bezmatrycowego.

Stowa kluczowe: ciagnienia bezmatrycowego, miedź, drut, chropowatość, plastyczność vantage is the achievement of a relatively large elongation in one pass (up to $60 \%$ ) which was shown by Kustra et al. [3] for magnesium alloy $\mathrm{MgCaO} .8$. One of the little-known possibilities of dieless drawing is the production of ultrafine wire. In this case, it is possible to additionally stretch wire obtained in the conventional way. This may allow obtaining a wire with a smaller diameter than the industry produces. This is especially true for copper and its alloys in connection with the development of microelectronics. Currently, the industry produces wire from copper and its alloys with a diameter of up to 10-12 microns. Conventional manufacturing of smaller-diameter wire is associated with difficulties in the manufacture of drawing dies. However, if such a wire is used as a workpiece for dieless drawing, it is possible to try to further reduce its diameter. The implementation of this idea requires the solution of two important issues that determine the purpose of this paper. The first is the opti- 
mal choice of temperature and deformation parameters to achieve maximum forming limit and uniformity of diameter along the length of the wire. The concept of dieless drawing, which allows to solve this problem, was proposed by Milenin [4] using the example of a magnesium alloy. The idea behind this approach is to perform multi-pass dieless drawing. Moreover, in each pass, the material must be in conditions of maximum hardening. This approach allows to reduce the irregularity of the diameter along the length of the wire and to increase the forming limit of material in the technological process. However, its effectiveness depends on the sensitivity of flow stress of the deformable material to strain and strain rate. With high sensitivity, the method becomes more efficient. The second problem is the increase of roughness during dieless drawing. This problem has become important due to the fact that the resulting roughness can be comparable to the diameter of the wire, and significantly reduce the forming limit. Thus, the solution to these problems requires both plastometric studies of the material and physical modelling to predict the forming limit and roughness of the wire under conditions of dieless drawing.

\section{MATERIAL PROPERTIES}

This paper investigates two materials - technically pure copper and CuZn37 alloy (brass). Plastometric studies of

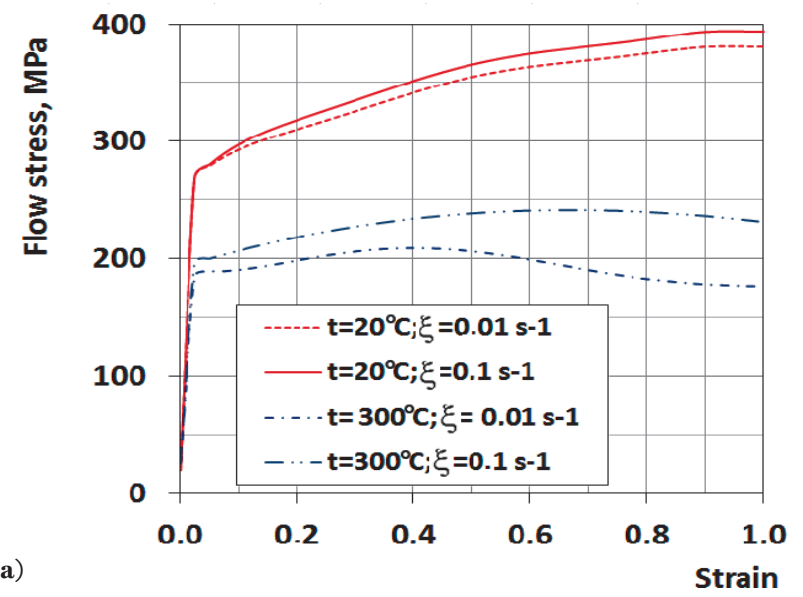

these materials were performed at a temperature range of 20-900 (copper) and 400-750 (CuZn37). The experiments were carried out with the use of GLEEBLE $(\mathrm{Cu})$ and Zwick 250 (CuZn37) machines. In experiments with the GLEEBLE machine, the hardware stabilisation of the material temperature was carried out during the test. The accuracy of this temperature control for strain rates of $0.01 \mathrm{~s}^{-1}$ and $0.1 \mathrm{~s}^{-1}$ was about $10^{\circ} \mathrm{C}$. In experiments eith the Zwick 250 machine, such a correction was impossible, therefore, an inverse analysis was applied based on modelling strain induced heating of the sample and friction. The methodology of inverse analysis was adapted for the deformation conditions in the Zwick 250 machine [5]. Typical stress-strain curves are shown in Figure 1 and Figure 2.

\section{PHYSICAL AND NUMERICAL SIMULATION OF DIELESS DRAWING PROCESS OF COPPER WIRE}

The next stage of this research was the study of surface roughness and technological plasticity. A special heating device, which creates the same temperature field in the wire as in the process of dieless drawing, was developed (item 2 in Figure 3a). Physical modelling of dieless drawing was carried out in the Zwick 250 machine. The diameter of

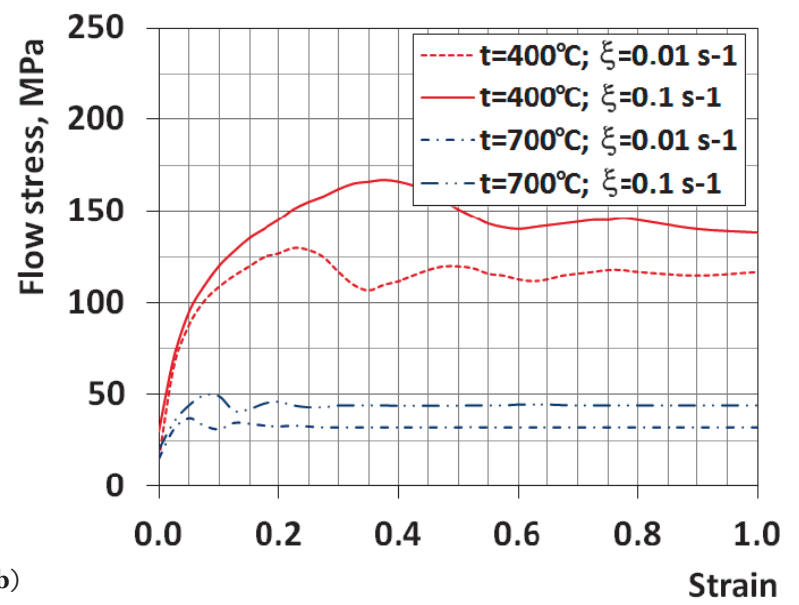

Fig. 1. Flow stress of commercial copper for temperature: a) $20^{\circ} \mathrm{C}$ and $\left.300^{\circ} \mathrm{C}, \mathrm{b}\right) 400^{\circ} \mathrm{C}$ and $600^{\circ} \mathrm{C}$ Rys. 1. Naprężenie uplastyczniające miedzi dla temperatur: a) $\left.20^{\circ} \mathrm{C} \mathrm{i} 300^{\circ} \mathrm{C}, \mathrm{b}\right) 400^{\circ} \mathrm{C} \mathrm{i} 600^{\circ} \mathrm{C}$
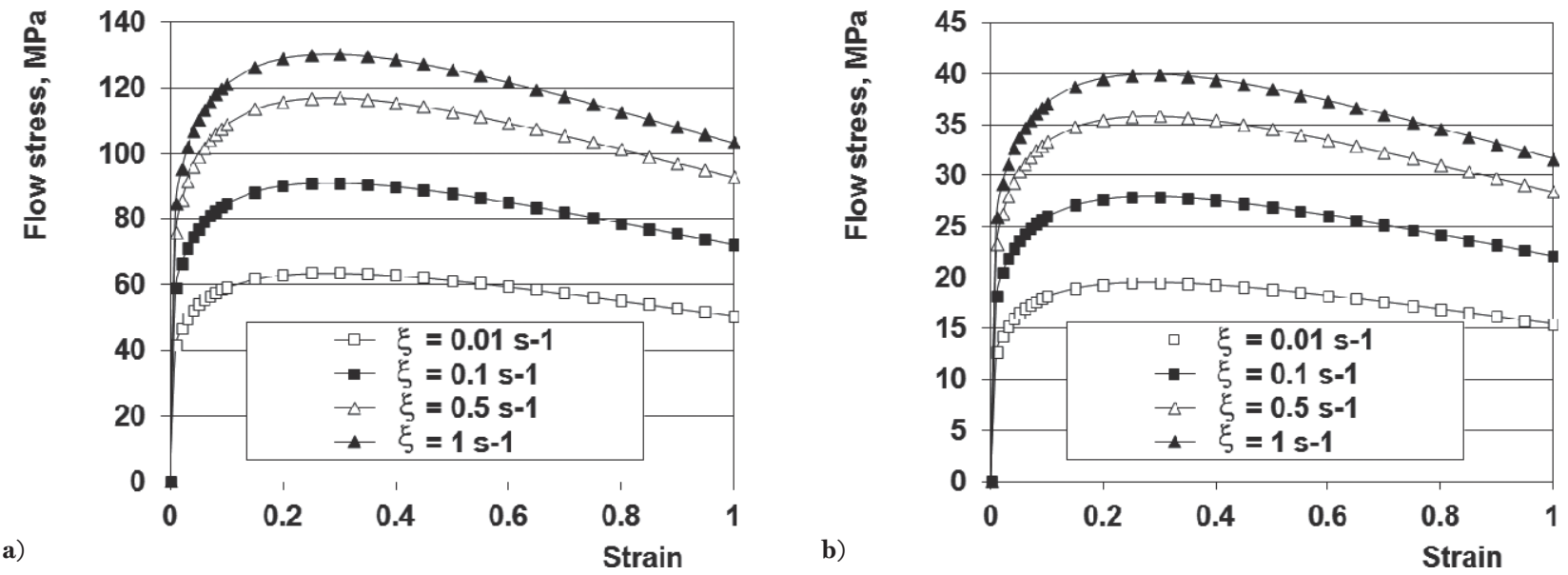

Fig. 2. Flow stress of CuZn37 alloy for temperature: a) $550^{\circ} \mathrm{C}$, b) $750^{\circ} \mathrm{C}$

Rys. 2. Naprężenie uplastyczniające stopu $\mathrm{CuZn37}$ dla temperatury: a) $\left.550^{\circ} \mathrm{C}, \mathrm{b}\right) 750^{\circ} \mathrm{C}$ 


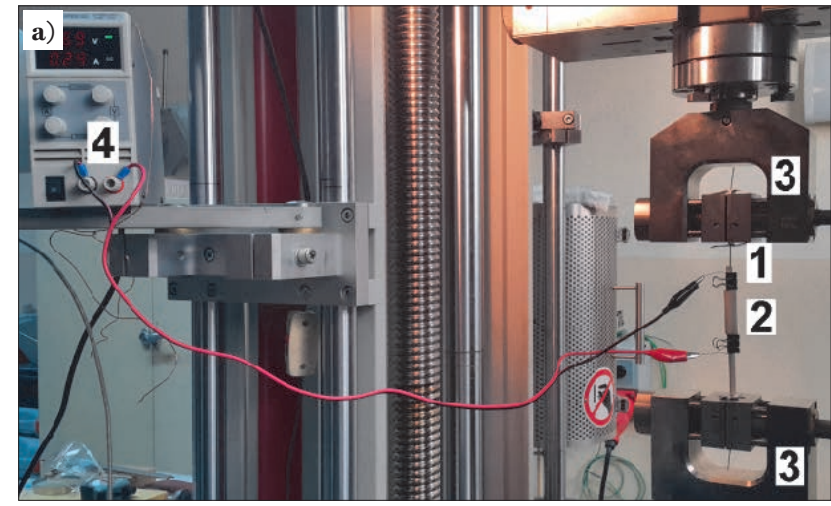

b)

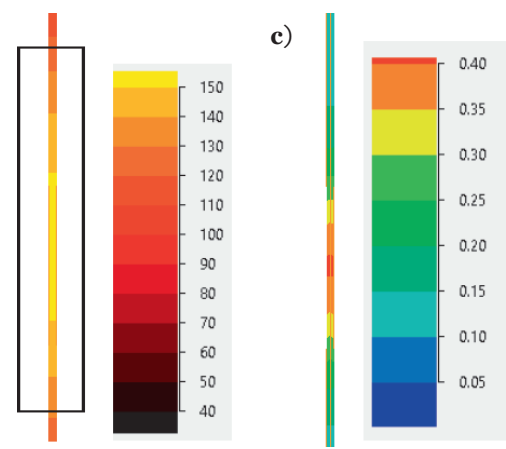

d)

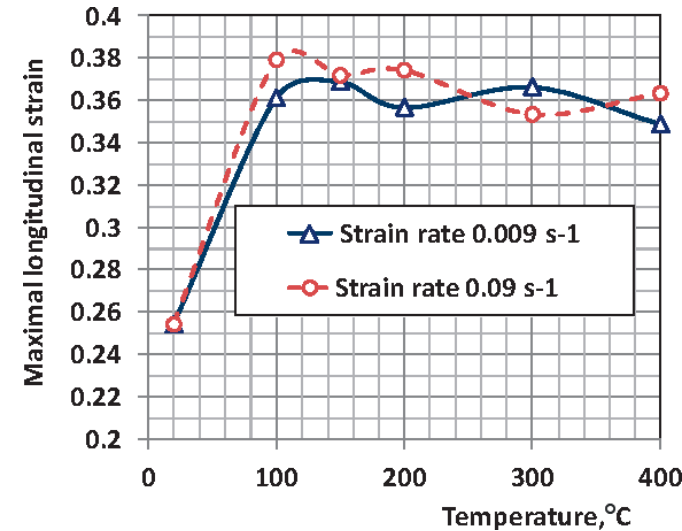

Fig. 3. Physical and numerical simulation of dieless drawing process: a) setup for physical modelling ( 1 - wire, 2 - heating device, 3 deformation module, 4 - power module for heating device), b) temperature distribution in deformation zone, c) strain distribution in zone of deformation, d) dependence of strain, associated with fracture in physical model, on temperature and strain rate

Rys. 3. Fizyczne oraz numeryczne modelowanie procesu ciągnienia bezmatrycowego: a) urządzenie do fizycznego modelowania (1 - drut, 2 - piec grzewczy, 3 - moduł odkształcenia, 4 - zasilanie układu grzewczego), b) rozkład temperatury w strefie odkształcenia, c) rozkład odkształcenia w strefie odkształcenia, d) zależność odkształcenia, powiązanego z pęknięciem w modelu fizycznym, od temperatury i prędkości odkształcenia

the deformed copper wire was $1 \mathrm{~mm}$. The stretching of local heated wires to its breaking was performed. The size of deformation corresponding to the fracture was determined by simulating this test using FEM (Figures 3,b and 3,c) and validated by measurement of wire diameter after the test. The dependence of the maximum achievable longitudinal strain under given conditions on temperature and strain rate was obtained (Figure $3 \mathrm{~d}$ ).

Roughness analysis was performed at the location of the maximum stable deformation (corresponding to item $D_{\text {min }}$ in Figure 4a). Roughness measurement was performed using SEM stereographic imaging. The temperature dependence of the surface roughness of the wire is shown in
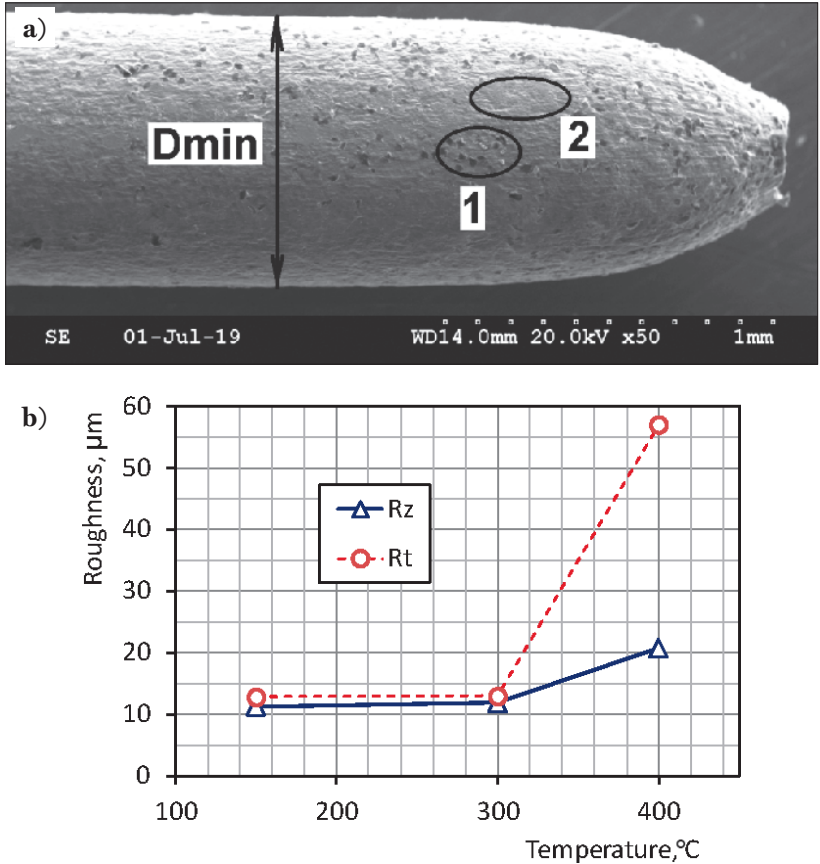

Fig. 4. Surface of the wire after breaking: 1 - domination of oxide formation, 2 - domination of strain induced roughness (a) and dependence of roughness in the deformation zone on the deformation temperature (b)

Rys. 4. Powierzchnia drutu po rozerwaniu: 1 - dominacja tworzenia się tlenków, 2 - dominacja chropowatości wywołanej odkształceniami (a) i zależność chropowatości w strefie odkształcenia od temperatury odkształcenia $(b)$

Figure $4 \mathrm{~b}$. As it can be seen in Figure 4, the overall roughness forms both an oxide layer and strain induced roughness (for example, items 1 and 2 in Figure 4a).

\section{DISCUSSION}

In accordance with the concept of multi-pass dieless drawing, during each pass, the material should be in a state of hardening, which means that the sensitivity of flow stress to strain and the strain rate should be significant and positive. The obtained hardening curves allow to select the strain temperature corresponding to the maximum forming limit in technological process. However, the results of this analysis for copper and brass are fundamentally different. As follows from Figure 1, at high temperatures, copper has a complex stress-strain relationship. At the same time, a noticeable zone of strain hardening is available at $400^{\circ} \mathrm{C}$ for strain below 0.2 . However, with a strain of more than 0.05 , the intensity of hardening (the slope of the flow stress curve to the axis of the strain) decreases. On the other hand, at $400^{\circ} \mathrm{C}$, an intensive growth of surface roughness is observed in the samples (Figure 5). This limits the deformation temperature to $300^{\circ} \mathrm{C}$. However, at this temperature, the hardening of copper is very insignificant (curves in Figure 1a). This fact significantly reduces the possibility of improving the forming limit in the technological process by using multi-pass dieless drawing. On the other hand, the ductility of copper (maximum longitudinal strain on Figure 3d) under the conditions of dieless drawing is maximum at $100-150^{\circ} \mathrm{C}$. This allows to choose a variant of a single-pass process with a low temperature in the deformation zone $\left(100-150^{\circ} \mathrm{C}\right)$ for pure copper. The flow stress of brass (Figure 2) shows a rather monotonous intensive hardening to a strain of 0.15. At the 


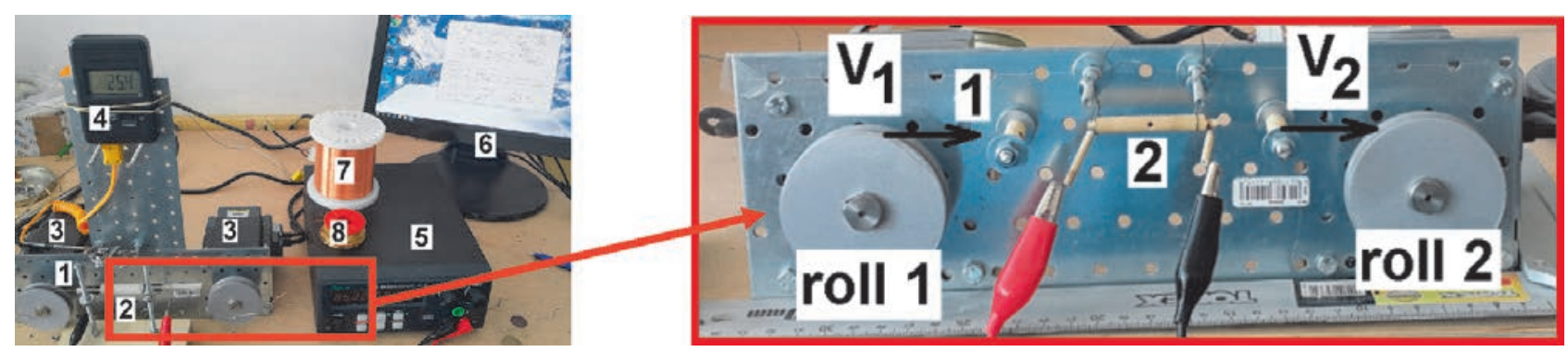

Fig. 5. Setup for dieless drawing of wire: 1 - wire, 2 - heating device, 3 - engines, 4 - module for measurement of temperature inside heating device, 5 - power supply for heating device, 6 - control computer with setup software, 7, 8 - initial wire made of CuZn37 and copper

Rys. 5. Urządzenia do realizacji procesu ciągnienia bezmatrycowego: 1 - drut, 2 - urządzenie grzewcze, 3 - silniki, 4 - moduł do pomiaru temperatury wewnątrz urządzenia grzewezego, 5 - zasilacz do urządzenia grzewczego, 6 - komputer sterujący z dedykowanym oprogramowaniem, 7, 8 - drut wsadowy ze stopu CuZn37 oraz miedzi

same time, brass is much less susceptible to corrosion than copper. Consequently, the deformation temperature can be selected at a wide range $\left(400-750^{\circ} \mathrm{C}\right)$, and the maximum strain value in one pass should be set to about 0.15 .

\section{PRACTICAL IMPLEMENTATION}

For practical implementation of the process parameters, a special setup was developed (Figure 5). The setup software controls the linear rotation rates of the rollers $\left(V_{1}\right.$ and $\left.V_{2}\right)$. The amount of strain of the wire in the heated zone 2 is determined from the condition of constant volume for $V_{2}>V_{1}$ :

$$
\varepsilon=1-\frac{V_{1}}{V_{2}}
$$

When performing the experiment, the calculated longitudinal strain in a single pass was 0.16 . For brass, 4 passes were made on a wire with an initial diameter of $0.5 \mathrm{~mm}$ (in pass 5 the wire broke down). The maximum achieved longitudinal strain was 0.55 , which corresponded to the final wire diameter of $0.38 \mathrm{~mm}$ (Figure 6). The maximum longitudinal strain achieved in a conventional dieless drawing process was 0.36 , which is significantly less than in the proposed multi-pass process.

Copper drawing was investigated on a wire with a diameter of $0.1 \mathrm{~mm}$. The maximum strain before breaking the wire was 0.2 . This corresponded to a final wire diameter of $0.09 \mathrm{~mm}$.

\section{CONCLUSIONS}

1. The paper studies the flow stress of technical copper and brass. The results showed that brass has a more stable

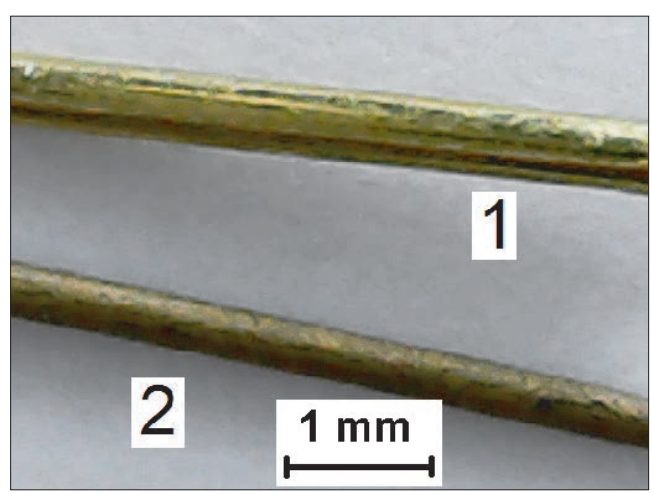

Fig. 6. Wires made of the CuZn37 alloy before (1) and after (2) dieless drawing

Rys. 6. Drut ze stopu CuZn37 przed (1) i po (2) procesie ciągnienia bezmatrycowego

hardening interval on the stress-strain curve. That is why this material is more promising for multi-pass dieless drawing. The dieless drawing experiments confirm this statement.

2. Ductility of copper in the conditions of dieless drawing reaches the maximum at $100-150^{\circ} \mathrm{C}$. The forming limit of a copper wire with a diameter of $1.0 \mathrm{~mm}$ is much higher than that of a wire of $0.1 \mathrm{~mm}$.

3. The surface roughness of the copper wire after dieless drawing increases significantly at a deformation temperature above $300^{\circ} \mathrm{C}$. The roughness is associated both with the formation of oxides and strain induced roughness.

\section{Acknowledgements}

The work was supported by the NCN of Poland, Project No. 2017/27/B/ST8/01471.

\section{REFERENCES}

[1] V. Weiss, R.A. Kot. Dieless wire drawing with transformation plasticity. Wire J., 1969, 9, p. 182-189.

[2] S. Supriadi, T. Furushima, K. Manabe. Development of Precision Profile Control System with Fuzzy Model and Correction Function for Tube Dieless Drawing. J. Solid Mech. Mater. Eng., 2011, 5 (12), p. 1059-1070.

[3] P. Kustra, A. Milenin, B. Płonka, T. Furushima. Production Process of Biocompatible Magnesium Alloy Tubes Using Extrusion and
Dieless Drawing Processes. J. Mater. Eng. Perform., 2016, 25 (6), p. 2528-2535.

[4] A. Milenin. Rheology-based approach of design the dieless drawing processes. Arch. Civil and Mech. Eng., 2018, 18 (4), p. 1309-1317.

[5] A. Milenin, P. Kustra, M. Paćko. Mathematical model of warm drawing of $\mathrm{MgCaO} .8$ alloy accounting for ductility of the material. Computer Methods in Materials Science, 2010, 10, p. 69-79. 